\title{
Ontogenetic changes in leaf traits of tropical rainforest trees differing in juvenile light requirement
}

\author{
Nico C. Houter • Thijs L. Pons
}

Received: 27 January 2011/Accepted: 11 October 2011/Published online: 30 October 2011

(c) The Author(s) 2011. This article is published with open access at Springerlink.com

\begin{abstract}
Relationships between leaf traits and the gap dependence for regeneration, and ontogenetic changes therein, were investigated in juvenile and adult tropical rainforest tree species. The juveniles of the 17 species included in the study were grown in high light, similar to the exposed crowns of the adult trees. The traits were structural, biomechanical, chemical and photosynthetic. With increasing species gap dependence, leaf mass per area (LMA) decreased only slightly in juveniles and remained constant in adults, whereas punch strength together with tissue density decreased, and photosynthetic capacity and chlorophyll increased. Contrary to what has been mostly found in evergreen tropical rainforest, the trade-off between investment in longevity and in productivity was evident at an essentially constant LMA. Of the traits pertaining to the chloroplast level, photosynthetic capacity per unit chlorophyll increased with gap dependence, but the chlorophyll $a / b$ ratio showed no relationship. Adults had a twofold higher LMA, but leaf strength was on average only about 50\% larger. Leaf tissue density, and chlorophyll and leaf $\mathrm{N}$ per area were also higher, whereas chlorophyll and leaf $\mathrm{N}$ per unit dry mass were lower. Ranking of the species, relationships between traits and with the gap dependence of the species were similar for juveniles and adults.
\end{abstract}

Communicated by Gerardo Avalos.

Electronic supplementary material The online version of this article (doi:10.1007/s00442-011-2175-x) contains supplementary material, which is available to authorized users.

N. C. Houter · T. L. Pons ( $\square)$

Department Plant Ecophysiology,

Institute of Environmental Biology, Utrecht University,

Padualaan 8, $3508 \mathrm{CH}$ Utrecht, The Netherlands

e-mail: T.L.Pons@uu.nl
However, the magnitudes of most ontogenetic changes were not clearly related to a species' gap dependence. The adaptive value of the leaf traits for juveniles and adults is discussed.

Keywords Gap dependence - LMA - Photosynthesis . Punch strength $\cdot$ Shade tolerance

\section{Introduction}

A closed evergreen rainforest is characterized by low light availability on the forest floor and a vertical gradient of increasing irradiance towards the top of the canopy. A disturbance such as that caused by tree falls, creates a gap in the canopy and introduces horizontal variation, which is the starting point of dynamical changes in microclimatic conditions (Chazdon et al. 1996). Most late-successional tropical rainforest trees are typically shade tolerant as juveniles, but are exposed to full daylight as adult trees when they have gained access to the canopy. Such trees cover a broad range of light conditions during their development. Typical early-successional species need canopy gaps or large disturbances throughout their life cycle. These shade avoiding species experience less change in light conditions during their development. Not all species can unequivocally be allocated to one of the abovementioned groups. The light requirement for regeneration of species is thus preferably considered as a continuum (Popma and Bongers 1988; Osunkoya et al. 1994; Poorter et al. 2004; Coste et al. 2005).

Several studies have shown that functional leaf traits vary systematically with a species' juvenile light requirement (Valladares and Niinemets 2008). Evergreen species in moist tropical rainforest that are not or only to a limited 
extent dependent on gaps generally have leaves with a higher mass per area (LMA) that are better defended against herbivory and damage in general, and have a longer lifespan than gap-dependent species (Bongers and Popma 1990; Coley and Barone 1996; Westoby et al. 2002; Poorter and Bongers 2006). They also have a lower photosynthetic capacity under otherwise similar conditions (Reich et al.1992; Raaimakers et al. 1995). This trade-off between investment in defense and in physiological functions, known as the growth-survival or the resource availability hypothesis, has not only been found in tropical rainforest but also in other environments (Mooney and Gulmon 1982; Coley et al. 1985).

Saplings acclimate to the variable light climate at the forest floor by adjusting leaf traits. Numerous studies indicate that at the leaf level plants growing in the shade compared to their counterparts at high irradiance have thinner leaves and a lower leaf LMA, which goes on the expense of photosynthetic capacity per unit leaf area (Lambers et al. 2008; Poorter et al. 2009). Also, leaf strength is reduced (Onoda et al. 2008). This change with shade acclimation is opposite to the increase in LMA with adaptation to shade that is mostly found in evergreen tropical trees (Veneklaas and Poorter 1998; Lusk et al. 2008). Leaf trait values change during ontogeny (Thomas and Winner 2002; Niinemets 2006). Adult trees typically have thicker leaves with higher LMA and dry matter density, and their leaves are tougher (Martinez-Garza and Howe 2005) with sometimes a higher photosynthetic capacity per unit area compared to sapling leaves (Pearcy 1987; Thomas and Bazzaz 1999; Rijkers et al. 2000; Kenzo et al. 2006). It is, however, not always clear from these studies to what extent the reported changes with ontogeny are developmentally determined or environmentally induced, because tree size varied not always independently of irradiance.

An important determinant of the longer lifespan of leaves of shade-tolerant trees is their greater toughness (Matsuki and Koike 2006; Alvarez-Clare and Kitajima 2007; Kitajima and Poorter 2010). This term is generally used to indicate the resistance of leaves against mechanical damage. However, it has recently been used to more specifically denote the energy required to fracture the leaf lamina per unit fracture area. The often used punch-and-die test, as also employed in this study, measures the force to punch a leaf, and is more appropriately called punch strength (Aranwela et al. 1999; Onoda et al. 2008). Leaf strength did not increase in proportion with LMA in sun leaves compared to the thinner shade leaves (Onoda et al. 2008; Lusk et al. 2010). Possibly, the higher LMA and the greater thickness of adult compared to juvenile tree leaves is also not associated with a proportional increase in strength.
Photosynthetic capacity relative to the amount of chlorophyll is an important parameter for the characterization of acclimation to irradiance at the chloroplast level (Anderson et al. 1995). In high light, photon absorption is not a limiting factor for photosynthesis and photosynthetic capacity is generally high relative to the amount of chlorophyll. However, in low light environments, photon absorption limits photosynthetic rates and shade-acclimated leaves typically have more chlorophyll relative to photosynthetic capacity (Evans 1989a; Hikosaka and Terashima 1996; Pons and Anten 2004). Evans (1989b) founda lower photosynthetic capacity per unit chlorophyll in evergreen trees compared to herbaceous plants when grown under identical light conditions, and Feng et al. (2004) for a few shade-tolerant compared to -intolerant tropical tree species. However, the trait is not unequivocally related to adaptation to shade in herbaceous plants (Murchie and Horton 1997). An important question thus remains to what extent photosynthetic capacity per chlorophyll is related to the juvenile light requirement in tropical rainforest trees when a larger range of species is investigated.

A first question that was addressed is to what extent leaf traits at the leaf and chloroplast level are associated with the regeneration niche of tropical rainforest trees. To answer this question, tree species were selected that covered a wide range of requirement for canopy gaps for their regeneration. Trait values are plotted against an index of gap dependence, which is equivalent to the juvenile light requirement, which is equivalent to the inverse of juvenile shade tolerance. Since trait values vary not only with ontogeny but also with growth condition, leaves were sampled from saplings that were experimentally grown in a large gap and from adult trees, thus making light conditions for the leaves of the juveniles and adults as similar as possible. This also allows the addressing of the second question, to what extent the relationships with a species regeneration niche are consistent across ontogenetic stages. The change in leaf trait values with ontogeny is likely to be different between species, which raises a third question, to what extent these ontogenetic changes are associated with a species' juvenile light requirement. Finally, given the contrasting natural environment of the two ontogenetic stages, a fourth question is addressed regarding the functional significance of the leaf traits in juvenile and adult trees.

\section{Materials and methods}

Study site

The study was carried out in a largely undisturbed forest in Central Guyana at about $50 \mathrm{~km}$ south of the township 
Mabura Hill in the West-Pibiri compartment of the local timber concession $\left(5^{\circ} 02^{\prime} \mathrm{N}, 58^{\circ} 37^{\prime} \mathrm{W}\right)$. The dominant soil is a haplic Ferralsol, locally known as brown sandy soil. It is a highly weathered acidic soil that has a high iron, aluminum and manganese content, and is low in available nutrients (van Kekem et al. 1996). Average annual precipitation is around 2,800 mm (van Dam 2001).

\section{Plant material}

Young saplings and adult trees of 17 species that are common in the area were used for the study. The species differ in their requirement of canopy gaps for their regeneration. To what extent they depend on gaps was characterized for each species in a similar way as done by Osunkoya et al. (1994) and Mostacedo and Fredericksen (1999). The species were assigned to one of five categories by one of us (N.C. Houter), an experienced tree spotter (S. Roberts) and three ecologists with a long-standing working experience in the local forest (P. van der Hout, H. ter Steege and R.C. Zagt). The categories were based on the occurrence of seedlings and small saplings in canopy gaps, (1) mostly under a closed canopy and occasionally in small gaps, (2) mostly in small gaps and under a closed canopy, (3) mostly in gaps of different sizes and occasionally under a closed canopy, (4) exclusively in gaps of different sizes and not under a closed canopy of undisturbed forest, and (5) typically in large gaps and clearings. The results were averaged and the means were used as an index of association of a species as juveniles with canopy gaps, the gap association index (GAI). Species names and their gap association index are shown in Table 1. This index is thus representative for a species light requirement for regeneration and is inversely related to its shade tolerance. Species are further referred to with their genus names.

\section{Experimental set up and leaf sampling}

Changes in leaf trait values associated with ontogeny were studied by comparing juveniles growing in a large gap with adult trees growing in full daylight. Seedlings (10 per species) were planted in a large approximately circular gap of around $2,400 \mathrm{~m}^{2}$. They were raised from seed in a nursery or alternatively collected in the surrounding forest. Trials had shown that it was difficult to grow shade-tolerant species in the high light environment of the large gap. By nursing the seedlings during a short period after planting, it was possible to also grow these species there in a common garden experiment. A plot of approximately $130 \mathrm{~m}^{2}$ was prepared by excavating roots of surrounding trees. Litter from the surrounding forest was put on top of the soil and the plants received $5 \mathrm{~g}$ of slow release fertilizer (Osmocote plus, release time $2-3$ months) at planting. The plants, spaced $0.8 \mathrm{~m}$ apart, were shaded for 1 or 2 months until growth had resumed. Water stress was avoided by watering the plants during dry periods. At the time of sampling, cotyledons were fully exhausted, hence plants were beyond the seedling stage. Recently matured leaves from eight plants per species that had fully developed in the gap environment after the nursing period were sampled for the measurements. The plants had grown in the gap for about 5 months and had a height of $27 \pm 13 \mathrm{~cm}$ (mean \pm SD).

Adult sample trees were selected that had their crowns partly exposed, the upper part of their crowns fully exposed, or the crowns exposed on all sides, referring to the crown illumination indices 3,4 and 5, respectively, of Clark and Clark (1992). The leaves were sampled from the exposed part of the crowns. In the case of the small shadetolerant species Oxandra, the most exposed individuals were selected and leaves were taken from the upper part of the somewhat shaded crowns. Sampling was done by means of a shotgun on eight trees per species. Leaves were immediately put between moist filter paper until further processing. They were measured for thickness, area, fresh and dry mass, punch strength, chlorophyll, nitrogen and the light saturated rate of photosynthesis. Sampling was done between in November and December 1998 (adults) and March and April 2000 (juveniles), when daily irradiance was around $28 \mathrm{~mol} \mathrm{~m}^{-2}$ day $^{-1}$ in a large clearing.

\section{Photosynthetic parameters}

Photosynthetic capacity of the young saplings was measured as the light-saturated rate of electron transport per unit leaf area $\left(\mathrm{ETR}_{\mathrm{LA}}\right)$. A mini-PAM fluorometer (Walz, Effeltrich, Germany) was used with the leaf clip holder (2030-B) for measurement of the quantum yield of PSII in the light ( $\Phi$ PSII $=\Delta F / F_{m}^{\prime}$ ) and photon flux density (PFD). Observations in the gap were done in the morning shortly after direct sunlight hit the sample leaf (between 0700 and 0900 hours). When required, a halogen lamp was used to increase irradiance to saturating levels. The intensity of the measuring light and the irradiance of actinic light required for light saturation in each species were established in preliminary measurements. Irradiance was reduced when $\Delta F / F_{m}^{\prime}$ was lower than 0.2 . The saturating pulse was set at its maximum value $\left(6 \mathrm{mmol} \mathrm{m} \mathrm{m}^{-2} \mathrm{~s}^{-1}\right) . \mathrm{ETR}_{\mathrm{LA}}$ was calculated according to Genty et al. (1989) as ETR $=$ PFD $\times$ ФPSII $\times \alpha \times \beta$. The leaf absorptance $(\alpha)$ was derived from

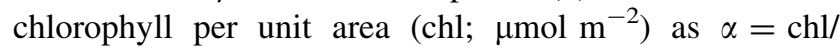
$(\mathrm{chl}+76)$ (Evans and Poorter 2001), and an equal partitioning of photon absorption between the two photosystems was assumed $(\beta=0.5)$.

ETR measurements on attached leaves could not be performed on adult tree leaves. Instead, detached leaves 
Table 1 The species used in the study with family name and gap association index $(G A I)$

The GAI ranges from 1 to 5 , where low values indicate that regeneration from seed is predominantly found under a closed canopy and in small gaps and high numbers indicate predominant regeneration in large gaps and clearings. Values are the mean $( \pm \mathrm{SD})$ of five estimates

\begin{tabular}{|c|c|c|}
\hline Species & Family & GAI \\
\hline Oxandra asbeckii (Pulle) R.E. Fr. & Annonaceae & $1.0 \pm 0.0$ \\
\hline Mora gongrijpii (Kleinh.) Sandw. & Leguminosae (Caesalp.) & $1.6 \pm 0.9$ \\
\hline Eschweileria sagotiana Miers & Lecythidiaceae & $1.7 \pm 0.6$ \\
\hline $\begin{array}{l}\text { Chlorocardium rodiei (Schomb.) Rohwer. } \\
\text { Richter and v.d. Werff }\end{array}$ & Lauraceae & $1.8 \pm 0.8$ \\
\hline Vouасароиа macropetala Sandw. & Leguminosae (Caesalp.) & $1.8 \pm 1.3$ \\
\hline Catostemma fragrans Benth. & Bombacaceae & $2.3 \pm 0.7$ \\
\hline $\begin{array}{l}\text { Licania heteromorpha Benth. var. } \\
\text { perplexans Sandw. }\end{array}$ & Chrysobalanaceae & $2.3 \pm 1.3$ \\
\hline Ormosia coccinea (Aubl.) Jacks. & Leguminosae (Papil.) & $2.5 \pm 0.7$ \\
\hline Hymenaea courbaril L. var. courbaril & Leguminosae (Caesalp.) & $3.1 \pm 1.3$ \\
\hline Pentaclethra macroloba (Willd.) Kuntze & Mimosoideae & $3.2 \pm 0.4$ \\
\hline Carapa guianensis Aublet & Meliaceae & $3.3 \pm 1.4$ \\
\hline $\begin{array}{l}\text { Peltogyne venosa (Vahl) Benth. subsp. } \\
\text { densiflora (Spruce ex Benth.) M.F.Silva }\end{array}$ & Leguminosae (Caesalp.) & $3.8 \pm 1.0$ \\
\hline $\begin{array}{l}\text { Sclerolobium guianense Benth. Var. } \\
\text { Guianense }\end{array}$ & Leguminosae (Caesalp.) & $4.6 \pm 0.4$ \\
\hline Goupia glabra Aublet & Celastraceae & $4.7 \pm 0.4$ \\
\hline Laetia procera (Poepp.) Eichler & Flacourtiaceae & $5.0 \pm 0.0$ \\
\hline $\begin{array}{l}\text { Jacaranda copaia (Aubl.) D.Don subsp. } \\
\text { Copaia }\end{array}$ & Bignoniaceae & $5.0 \pm 0.0$ \\
\hline Cecropia obtusa Tréc. & Moraceae & $5.0 \pm 0.0$ \\
\hline
\end{tabular}

were sampled in the morning and kept on moist filter paper in a box until measurement of photosynthetic capacity in the afternoon. Photosynthesis measurements were carried out with a leaf disc oxygen electrode (LD-II; Hansatech, Norfolk, UK) in $5 \% \mathrm{CO}_{2}$ in air. The electrode chamber was temperature controlled at $25^{\circ} \mathrm{C}$. Lighting was with a $50-\mathrm{W}$ halogen lamp and neutral density glass filters. Irradiance was increased until maximum $\mathrm{O}_{2}$ evolution rates were found.

Structural, chemical and biomechanical parameters

Leaves used for the photosynthesis measurements were stored between moistened filter paper until further processing the same day. Leaf blades, or in case of large leaves such as Cecropia about $100 \mathrm{~cm}^{2}$ sampled from the distal part of the blade, were measured for area with a leaf area meter (LI-1100; Licor, USA) and fresh mass. Dry mass was measured after 3 days at $70^{\circ} \mathrm{C}$. Leaf mass per area (LMA) was calculated from the dry mass to area ratio. Thickness of the fresh leaf was measured with a thickness gauge (resolution $0.01 \mathrm{~mm}$ ) excluding veins.

Chlorophyll was extracted in $5 \mathrm{ml}$ dimethylformamide (DMF) from three leaf discs $\left(1.9 \mathrm{~cm}^{2}\right)$. After storage in darkness at room temperature for 4-10 days until extraction was complete, absorptance was measured with a spectrophotometer (UV/VIS 120-01; Shimadzu, Kyoto,
Japan) and chlorophyll $a$ and $b$ were calculated according to Inskeep and Bloom (1985). Total leaf nitrogen per unit dry mass was measured on ground leaf material using an elemental analyzer (Carlo Erba, Milan, Italy).

Leaf strength was measured on separate but similar leaves as used for the previous measurements according to Feeny (1970) and Choong et al. (1992). A leaf was put between two acrylic plates. The lower one had a hole of $5 \mathrm{~mm}$ diameter and the upper one of $2 \mathrm{~mm}$. A freely moving metal rod (cross-section $2.5 \mathrm{~mm}^{2}$ ) with a beaker on top rested perpendicularly on the leaf. The force on the leaf was slowly increased by filling the beaker with water. The total weight when the rod penetrated the leaf was used to calculate the punch strength by dividing it through the cross-sectional area of the rod.

\section{Calculations and statistical analyses}

A two-way ANOVA was used to evaluate species specific differences in ontogenetic effects on leaf trait values. The relative change in a trait value per species associated with ontogeny (ontogenetic effect) was calculated as the difference between the means of the adults and juveniles divided by the juvenile value. Relationships of the species mean leaf trait values with the gap association index for the two developmental stages, and the ontogenetic effect, was evaluated with regression analysis. Maintenance of species 
ranking between developmental stages was calculated by pairwise comparison of the species mean trait values. Significance was evaluated by calculating Kendall's correlation coefficient. Correlation between leaf traits was evaluated with the Spearman correlation coefficient (2sided). The association between leaf traits of juveniles and adults was analyzed with a principal component analysis based on a correlation matrix. The statistical analyses were carried out using SPSS 18.

\section{Results}

The ANOVA revealed that large differences between species were evident for all leaf traits (Table 2). The effects of developmental stage were particularly strong. Species specific changes in leaf traits with developmental stage were also present as can be seen from the significant interactions. Regression analysis showed that several traits for juveniles and adults showed a relationships with the gap association index (GAI) (Table 3). This was only to a limited extent the case for the ontogenetic effect (Table 4). The results of a PCA analysis indicated that the relationship between traits were rather similar for juveniles and adults (Fig. 1). These aspects are described in further detail below.

\section{Leaf mass per area and strength}

A trend of a decreasing leaf mass per area (LMA) with the GAI was evident for juveniles (Table 3; Fig. 2), although the relation was not significant. Such a trend was absent for adults. LMA is made up of leaf thickness and tissue density (dry mass per volume). These traits were not related to the GAI in adults, but tissue density decreased significantly with GAI in juveniles (Table 3 ). The positive correlation between thickness and LMA indicates that much of the variation in LMA was the result of variation in thickness (Fig. 3). The smaller variation in density contributed less to variation in LMA. Some species showed combinations of thickness and density that deviated from the general trend such as juvenile Cecropia and adult Ormosia that had relatively thick leaves with low tissue density, and juvenile $V o$ иacapoua and adult Pentaclethra with relatively thin leaves with high density (Fig. 3, Supplement Table 1).

LMA increased substantially with ontogenetic development (101\%) (Table 3). This was on average the result of a stronger increase in thickness (54\%) compared to density (33\%) (Fig. 2, Table 4). A trend of an increasing ontogenetic effect with the GAI on LMA and density was evident, but the regressions were not significant (Table 4).
Table 2 The effect of species and ontogenetic stage and their interaction on leaf trait values

\begin{tabular}{|c|c|c|c|c|}
\hline & $\begin{array}{l}\text { Species } \\
F\end{array}$ & $\begin{array}{l}\text { Ontogeny } \\
F\end{array}$ & $\begin{array}{l}\text { Species } \times \\
\text { ontogeny } \\
F\end{array}$ & $r^{2}$ \\
\hline LMA & $21.19 * *$ & $1,152.13 * *$ & $9.66^{* *}$ & 0.882 \\
\hline Thickness & $43.49 * *$ & $577.03 * *$ & $14.55 * *$ & 0.868 \\
\hline Density & $8.78 * *$ & $167.49 * *$ & $4.15^{* *}$ & 0.635 \\
\hline Punch strength $_{\text {LA }}$ & $35.83 * *$ & $146.13 * *$ & $4.21 * *$ & 0.783 \\
\hline Punch strength $_{\mathrm{DM}}$ & $22.92 * *$ & $79.89 * *$ & $2.97 * *$ & 0.693 \\
\hline Chlorophyll LA $_{\text {L }}$ & $9.47 * *$ & $164.23 * *$ & $3.90 * *$ & 0.622 \\
\hline Chlorophyll $_{\mathrm{DM}}$ & $20.57 * *$ & $129.03 * *$ & $8.71 * *$ & 0.733 \\
\hline Chlorophyll $_{\mathrm{N}}$ & $12.54 * *$ & $54.57 * *$ & $7.86 * *$ & 0.637 \\
\hline Chlorophyll $a / b$ & $14.31 * *$ & $19.62 * *$ & $3.02 * *$ & 0.567 \\
\hline $\mathrm{N}_{\mathrm{DM}}$ & $30.53 * *$ & $89.30 * *$ & $2.87 * *$ & 0.736 \\
\hline $\mathrm{N}_{\mathrm{LA}}$ & $17.07 * *$ & $690.64 * *$ & $8.87 * *$ & 0.832 \\
\hline$A_{\mathrm{LA}}$ & $54.76 * *$ & - & - & - \\
\hline$A_{\mathrm{DM}}$ & $49.84 * *$ & - & - & - \\
\hline$A_{\mathrm{chl}}$ & $21.50 * *$ & - & - & - \\
\hline$A_{\mathrm{N}}$ & $37.87 * *$ & - & - & - \\
\hline
\end{tabular}

A two-way ANOVA was performed and $F$ and $r^{2}$ values are shown. A conservative threshold $P$ value of 0.01 was adopted because not all variables are fully independent. The ontogeny effect and the interaction was left out for the photosynthetic parameters because the stages could not be quantitatively compared

The level of significance: $* P<0.01$, ** $P<0.001$

$L M A$ leaf mass per area, $A$ rate of photosynthesis. Subscripts refer to the expression basis: leaf area $(L A)$, dry mass $(D M)$, chlorophyll $(\mathrm{chl})$ and nitrogen $(N)$.

Punch strength expressed per unit leaf area decreased significantly in juveniles with increasing gap dependence of the species (Table 3; Fig. 2). The trend was also apparent in adult trees, but the relation with the GAI was not significant (Table 3). Punch strength increased with ontogeny (32\%), but the trend of an increasing ontogenetic effect with GAI was also not significant (Table 4; Fig. 2).

Within each developmental stage when comparing species, punch strength increased more than expected when strength would increase in proportion with LMA (Fig. 4). However, the large increase in LMA with ontogeny resulted in less increase in strength. Consequently, punch strength per unit dry mass decreased with ontogeny in most species (mean -20\%) (Table 4), except in Licania and Peltogyne. Punch strength per mass decreased also with the GAI, but the change with ontogeny was not related to the GAI (Tables 3 and 4; Fig. 2). Ranking of the species for the two punch strength variables was maintained to a large extent between the two developmental stages (Table 4). Hence, gap-dependent species had weaker leaf tissue and the strength characteristics were to a considerable extent maintained with ontogenetic development. 
Table 3 Overall means for leaf traits and relationships of leaf trait values with the gap association index (GAI) for juvenile and adult trees

\begin{tabular}{|c|c|c|c|c|c|c|c|c|c|c|}
\hline & \multicolumn{4}{|c|}{ Juvenile trees } & \multicolumn{4}{|c|}{ Adult trees } & \multicolumn{2}{|c|}{ Comparison } \\
\hline & Mean & $a$ & $b$ & $r^{2}$ & Mean & $a$ & $b$ & $r^{2}$ & $a$ 's & $b$ 's \\
\hline LMA $\left(\mathrm{g} \mathrm{m}^{-2}\right)$ & 64.5 & 76.9 & -4.02 & $0.172^{\mathrm{ns}}$ & 127.0 & 133.3 & -2.1 & $0.011^{\mathrm{ns}}$ & $* * *$ & ns \\
\hline Thickness (mm) & 0.202 & 0.193 & 0.003 & $0.004^{\mathrm{ns}}$ & 0.301 & 0.313 & -0.004 & $0.005^{\mathrm{ns}}$ & $* * *$ & ns \\
\hline Tissue density $\left(\mathrm{kg} \mathrm{m}^{-3}\right)$ & 0.328 & 0.386 & -0.019 & $0.279 *$ & 0.427 & 0.444 & -0.006 & $0.014^{\mathrm{ns}}$ & $* * *$ & ns \\
\hline Punch strength ${ }_{\mathrm{LA}}\left(\mathrm{N} \mathrm{mm}^{-2}\right)$ & 0.934 & 1.383 & -0.145 & $0.269 *$ & 1.372 & 1.797 & -0.137 & $0.143^{\text {ns }}$ & $* *$ & ns \\
\hline Punch strength ${ }_{\mathrm{DM}}\left(\mathrm{N} \mathrm{mg}^{-1}\right)$ & 4.53 & 18.44 & -1.51 & $0.306^{*}$ & 4.43 & 14.01 & -1.04 & $0.260 *$ & $* *$ & ns \\
\hline Chlorophyll $_{\mathrm{LA}}\left(\mu \mathrm{mol} \mathrm{m}{ }^{-2}\right)$ & 0.385 & 0.215 & 0.055 & $0.564 * * *$ & 0.539 & 0.433 & 0.034 & $0.351^{*}$ & $* * *$ & ns \\
\hline Chlorophyll $_{\mathrm{DM}}\left(\mu \mathrm{mol} \mathrm{g} \mathrm{g}^{-1}\right)$ & 6.29 & 2.04 & 1.37 & $0.764 * * *$ & 4.53 & 3.64 & 0.29 & $0.100^{\mathrm{ns}}$ & $* * *$ & $* *$ \\
\hline Chlorophyll $_{\mathrm{N}}\left(\mathrm{mmol} \mathrm{mol}^{-1}\right)$ & 3.66 & 2.23 & 0.463 & $0.653 * * *$ & 3.08 & 2.95 & 0.042 & $0.007^{\mathrm{ns}}$ & $*$ & $*$ \\
\hline Chlorophyll $a / b\left(\mathrm{~mol} \mathrm{~mol}^{-1}\right)$ & 3.42 & 3.34 & 0.028 & $0.008^{\mathrm{ns}}$ & 3.22 & 2.99 & 0.075 & $0.082^{\text {ns }}$ & ns & ns \\
\hline $\mathrm{N}_{\mathrm{DM}}\left(\mathrm{mg} \mathrm{g}^{-1}\right)$ & 23.5 & 17.0 & 2.12 & $0.530 * * *$ & 20.5 & 17.4 & 1.01 & $0.140^{\mathrm{ns}}$ & $*$ & ns \\
\hline $\mathrm{N}_{\mathrm{LA}}\left(\mathrm{mmol} \mathrm{m}{ }^{-2}\right)$ & 106 & 97.9 & 2.56 & $0.033^{\mathrm{ns}}$ & 182.6 & 166.9 & 5.08 & $0.034^{\mathrm{ns}}$ & $* * *$ & ns \\
\hline 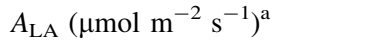 & 119 & 23.8 & 31.0 & $0.706 * * *$ & 13.99 & -4.42 & 5.97 & $0.741 * * *$ & - & - \\
\hline$A_{\mathrm{DM}}\left(\mathrm{nmol} \mathrm{g}^{-1} \mathrm{~s}^{-1}\right)^{\mathrm{a}}$ & 1.98 & 0.123 & 0.683 & $0.841 * * *$ & 0.118 & -0.050 & 0.054 & $0.770 * * *$ & - & - \\
\hline$A_{\mathrm{chl}}\left(\mu \mathrm{mol} \mathrm{mol}{ }^{-1} \mathrm{~s}^{-1}\right)^{\mathrm{a}}$ & 308 & 190 & 38.5 & $0.462 * * *$ & 25.23 & -3.90 & 9.44 & $0.762 * * *$ & - & - \\
\hline$A_{\mathrm{N}}\left(\mu \mathrm{mol} \mathrm{mol}{ }^{-1} \mathrm{~s}^{-1}\right)^{\mathrm{a}}$ & 1129 & 273 & 278 & $0.792 * * *$ & 76.6 & -14.4 & 29.5 & $0.786 * * *$ & - & - \\
\hline
\end{tabular}

The results of regression analysis is shown where $a$ denotes the intercept and $b$ the slope. Comparison of regression lines was done by ANCOVA. For abbreviations of traits see Table 2. For species specific mean leaf trait values see Supplemental Table 1

Significant regressions and comparisons: ns, ${ }^{*}, * *, * *$ (respectively, non-significant, $P<0.05, P<0.01, P<0.001$ )

${ }^{a}$ Photosynthetic units are in $\mu$ mol electrons for juveniles and in $\mu \mathrm{mol} \mathrm{O}_{2}$ for adult trees

Nitrogen, pigments and photosynthetic capacity

Leaf $\mathrm{N}$ concentrations in dry matter $\left(\mathrm{N}_{\mathrm{DM}}\right)$ of juveniles were somewhat higher compared to adult trees (13\%) (Table 3). $\mathrm{N}_{\mathrm{DM}}$ increased with GAI in juveniles, but not clearly in adult trees. The decrease with ontogeny was thus stronger for gap-dependent species (Table 4). As a consequence of the large increase in LMA with ontogeny, $\mathrm{N}$ expressed per leaf area $\left(\mathrm{N}_{\mathrm{LA}}\right)$ was much higher in adult trees compared to juveniles (75\%) (Table 4).

Leaves of adult trees had a higher chlorophyll content per unit area compared to juveniles (47\%) (Tables 3 and 4; Fig. 2). When chlorophyll was expressed per unit dry mass, values were lower for adult trees $(-23 \%)$ as a result of their much higher LMA. Gap-dependent species had higher chlorophyll per area for both developmental stages, but the positive relationship with the GAI was only maintained in juveniles when chlorophyll was expressed per unit dry mass (Table 3). Relationships were similar for chlorophyll per $\mathrm{N}$ (Tables 3 and 4; Fig. 2). The chlorophyll $a / b$ ratio was not associated with the species gap dependence and the values were rather similar for the two developmental stages (Tables 3 and 4).

Photosynthetic capacity was measured as the light saturated electron transport rate with chlorophyll fluorescence on attached leaves of juveniles. Values were expressed per leaf area $\left(A_{\mathrm{LA}}\right)$, dry mass $\left(A_{\mathrm{DM}}\right)$, chlorophyll $\left(A_{\mathrm{chl}}\right)$ and per leaf $\mathrm{N}\left(A_{\mathrm{N}}\right)$. All these photosynthetic parameters increased strongly with the GAI (Table 3; Fig. 2). Since chlorophyll fluorescence measurements could not be done on attached leaves of adult trees, photosynthetic capacity was measured on detached leaves as $\mathrm{O}_{2}$ production at $\mathrm{CO}_{2}$ saturation. Clear positive relationships of this measure of photosynthetic capacity with the GAI for all four expression bases were also observed among the 14 species adult trees that were included (Table 3; Fig. 2).

\section{Discussion}

Trait values of juveniles in high light conditions

Chlorophyll on all expression bases showed strong positive correlations with a species' gap dependence (Table 3). The large gap where the juveniles were growing is the natural environment of the gap-dependent species, but irradiance was high compared to where shade-tolerant saplings normally occur. The shade-tolerant juveniles were growing well and chlorophyll content was not particularly low in the gap. However, the same species growing in shade had similar chlorophyll contents compared to gap dependent species (results not shown). It is thus likely that the shadetolerant juveniles have suffered some light stress (Houter and Pons 2005) resulting in somewhat reduced chlorophyll 
Table 4 Relative ontogenetic changes

\begin{tabular}{llllllll}
\hline & Mean & \multicolumn{3}{l}{ Regression on GAI } & & $\begin{array}{l}\text { Rank } \\
\text { maintenance }\end{array}$ \\
\cline { 2 - 6 } & $\%$ & $a$ & $b$ & $r^{2}$ & $P$ & $\%$ \\
\hline LMA & 101.2 & 66.9 & 11.1 & 0.125 & $\mathrm{~ns}$ & $61^{\mathrm{ns}}$ \\
Thickness & 53.5 & 51.3 & 0.7 & 0.001 & $\mathrm{~ns}$ & $76^{* *}$ \\
Tissue density & 32.5 & 11.1 & 6.9 & 0.135 & $\mathrm{~ns}$ & $68^{*}$ \\
Punch strength $_{\mathrm{LA}}$ & 54.3 & 15.9 & 12.4 & 0.219 & $\mathrm{~ns}$ & $85^{* * *}$ \\
Punch strength $_{\mathrm{DM}}$ & -20.2 & -23.3 & 1.0 & 0.010 & $\mathrm{~ns}$ & $80^{* * *}$ \\
Chlorophyll $_{\mathrm{LA}}$ & 47.0 & 86.8 & -12.8 & 0.225 & $\mathrm{~ns}$ & $55^{\mathrm{ns}}$ \\
Chlorophyll $_{\mathrm{DM}}$ & -23.0 & 16.1 & -12.6 & 0.389 & $* *$ & $72^{*}$ \\
Chlorophyll $_{\mathrm{N}}$ & -12.8 & 20.8 & -10.8 & 0.300 & $*$ & $60^{\mathrm{ns}}$ \\
Chlorophyll $a / b$ & -5.3 & -8.8 & 1.1 & 0.025 & $\mathrm{~ns}$ & $70^{*}$ \\
$\mathrm{~N}_{\mathrm{DM}}$ & -12.6 & -2.0 & -3.4 & 0.258 & $*$ & $83^{* * *}$ \\
$\mathrm{~N}_{\mathrm{LA}}$ & 75.3 & 65.5 & 3.2 & 0.013 & $\mathrm{~ns}$ & $63^{*}$ \\
$A_{\mathrm{LA}}$ & - & - & - & - & - & $85^{* * *}$ \\
$A_{\mathrm{DM}}$ & - & - & - & - & - & $81^{* *}$ \\
$A_{\text {chl }}$ & - & - & - & - & - & $74^{*}$ \\
$A_{\mathrm{N}}$ & - & - & - & - & - & $77^{*}$ \\
\hline
\end{tabular}

The change was calculated per species as the percentage difference between the two [(adult - juvenile)/juvenile]. Presented are the mean change and a regression analysis of the relationship between the change and the GAI, where $a$ denotes the intercept and $b$ the slope. The right column depicts the percentage maintenance of ranking in a pairwise comparison of species between juveniles and adults. For abbreviations of traits see Table 2 . For species specific ontogenetic changes see Supplemental Table 2

Significant regressions and rank maintenance: $\mathrm{ns}, *, * *, * * *$ (respectively non-significant, $P<0.05, P<0.01, P<0.001)$

contents. Although less pronounced, adult shade-tolerant trees showed a similar trend of reduced chlorophyll per area with the GAI, whereas the high irradiance in the upper part of the canopy is the normal environment for these leaves. The similar trends of chlorophyll with juvenile light requirement in the two ontogenetic stages growing in high light are thus likely to represent an inherent one.

Acclimation of plants to canopy shade is generally accompanied by a shift from investment at the chloroplast level from more in photosynthetic capacity to more in light harvesting (Anderson et al. 1995). This is evident from a decrease in photosynthetic capacity per unit chlorophyll ( $\left.A_{\mathrm{chl}}\right)$. The decrease of $A_{\mathrm{chl}}$ with increasing shade tolerance at constant irradiance (Table 3 ) suggests that such a shift from investment in capacity of the photosynthetic apparatus to light harvesting may also be a form of shade adaptation. However, Murchie and Horton (1997) did not find a relationship of $A_{\mathrm{chl}}$ with shade adaptation in a comparative study of western European herbaceous plants. A similar shift was found for inherently slow-growing species that showed more investment in pigment protein complexes relative to photochemistry in comparison with inherently fast-growing species (Poorter and Evans 1998; Pons and

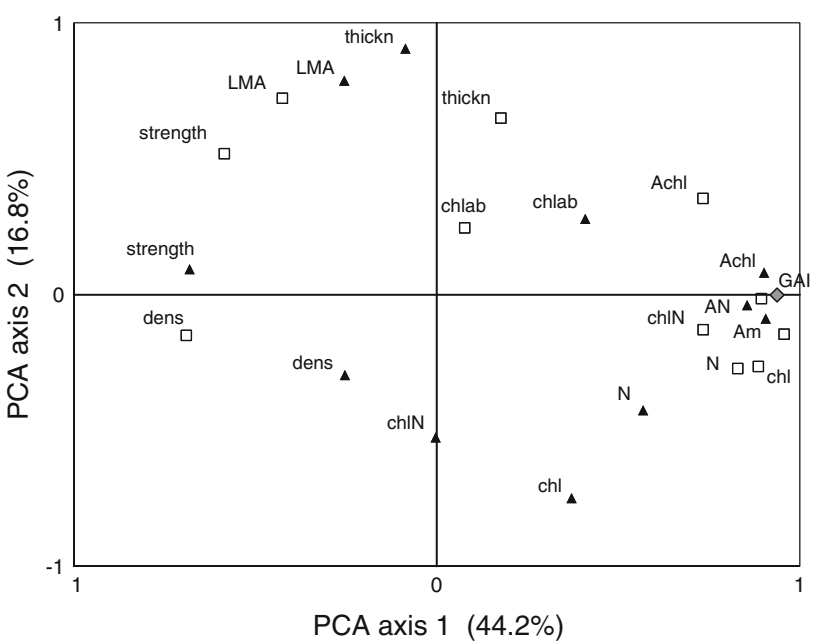

Fig. 1 Results of a principal component analysis (PCA). Factor loadings are shown on the axes for leaf traits of juvenile (open squares) and adult trees (closed triangles), and the gap association index (diamond). Traits expressed per leaf area were excluded from the analysis except LMA. Trait labels are abbreviated versions of the names mentioned in Table 2. The dry mass expression basis is not explicitly mentioned

Westbeek 2004) and slow-growing tropical trees compared to fast-growing herbaceous species (Evans 1989b). Gapindependent tropical tree species have lower inherent growth rates compared to gap-dependent species (Veneklaas and Poorter 1998). Feng et al. (2004) found indeed a higher $A_{\mathrm{chl}}$ for two light-requiring species compared to two shade-tolerant ones. A low photosynthetic capacity per unit chlorophyll seems to be of general occurrence in slowgrowing species, but is not necessarily related to shade adaptation. The chlorophyll $a / b$ ratio is also a component of acclimation to shade at the chloroplast level (Anderson et al. 1995). However, contrary to $A_{\mathrm{chl}}$, this trait, measured at the high irradiance of the gap, was not related to a species' gap dependence at all (Table 3).

Chlorophyll per unit leaf $\mathrm{N}\left(\mathrm{chl}_{\mathrm{N}}\right)$ is used as an indirect measure to describe relative investment of photosynthetic $\mathrm{N}$ in light harvesting (Niinemets 1997; Kull and Niinemets 1998; Rozendaal et al. 2006). $A_{\text {chl }}$, a more direct measure for the same purpose, should thus be negatively related to $\mathrm{chl}_{\mathrm{N}}$. However, the two were not clearly related (Fig. 1; Supplemental Table 3) and both decreased with decreasing species' gap dependence (Table 3; Fig. 2). The reason is that the proportion of total leaf $\mathrm{N}$ that is involved in photosynthesis increased with a species gap dependence as evident from the increasing photosynthetic nitrogen use efficiency $\left(A_{\mathrm{N}}\right)$ (Table 3; Fig. 2). This is also a well-known phenomenon among tropical trees (Reich et al. 1992; Raaimakers et al. 1995; Coste et al. 2005). Photosynthetic capacity was thus not proportional to leaf $\mathrm{N}$ (Fig. 5), and consequently $\mathrm{chl}_{\mathrm{N}}$ is not a good measure of the investment 

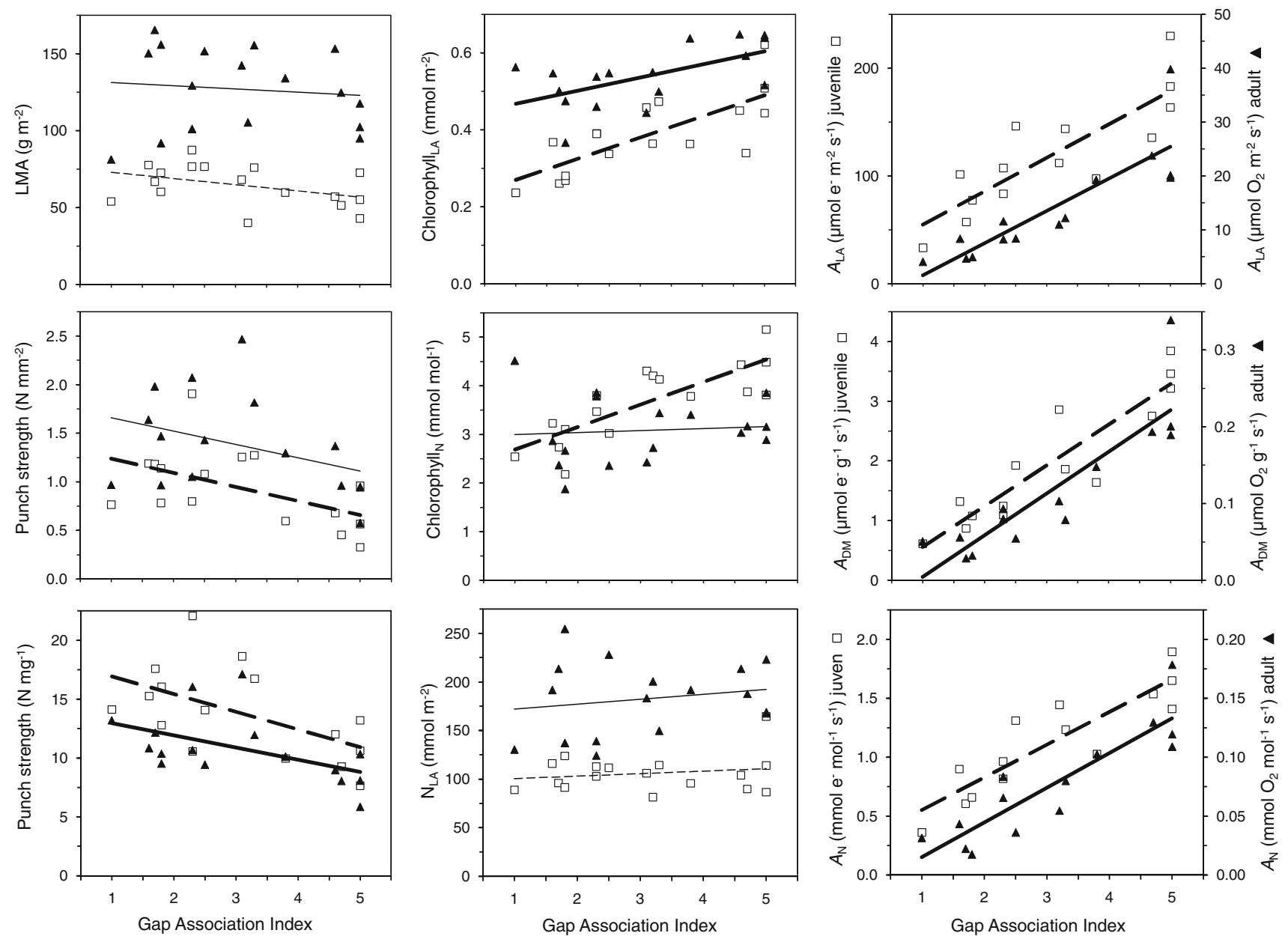

Fig. 2 Leaf traits of the 17 species involved in the study plotted against their gap association index (GAI). Trait values were measured on leaves from juvenile and adult trees (open squares and closed triangles, respectively). Bold regression lines are significant, thin lines are not $(P<0.05)$; dashed lines denote juveniles and continuous lines adults. For abbreviation of traits and regression parameter values see Tables 2 and 3. For species specific mean $( \pm$ SE) trait values see Supplemental Table 1
Fig. 3 Leaf thickness (a) and leaf tissue density (leaf dry mass per volume) (b) plotted against leaf mass per area (LMA). Significant correlations are depicted by thick trend lines, non-significant ones by thin lines; correlation coefficients are shown next to the lines $(* * P<0.01 ; * * * P<0.001)$. Juveniles: open squares and dashed lines; adults: closed triangles and continuous lines

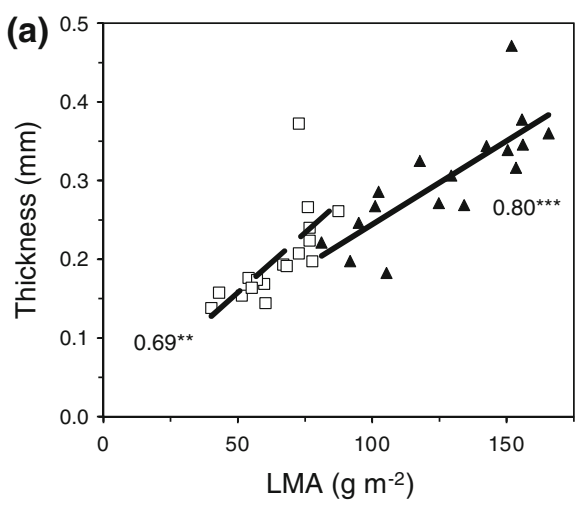

in light harvesting relative to photosynthetic capacity in a comparison of tropical tree species differing in shade tolerance.

The character of the leaf tissue changed with gap dependence of the species. Tissue density and punch

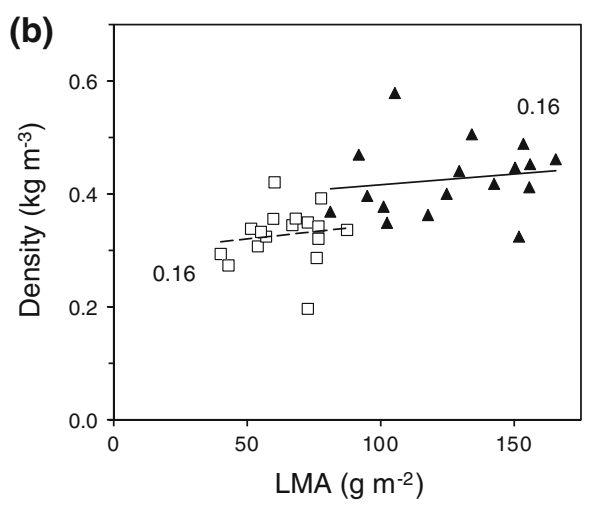

strength per dry mass increased with increasing shade tolerance, whereas nitrogen concentration $\left(\mathrm{N}_{\mathrm{DM}}\right)$ and photosynthetic capacity $\left(A_{\mathrm{DM}}\right)$ decreased (Table 3 ; Fig. 2). Increasing leaf strength with increasing shade tolerance was thus at the expense of the photosynthetic function of 


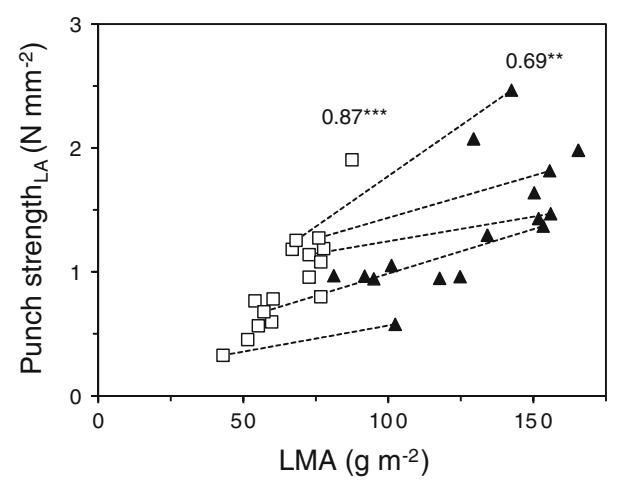

Fig. 4 Punch strength per area plotted against LMA. Correlation coefficients for juveniles (open squares) and adults (closed triangles) are shown above each series $(* * P<0.01 ; * * * P<0.001)$. For five species, values for juveniles and adults are connected with dashed lines. The species are from high to low punch strength, Hymenaea, Carapa, Chlorocardium, Sclerolobium, Jacaranda

the leaf as illustrated by the negative relationship between photosynthetic capacity $\left(A_{\mathrm{DM}}\right)$ and punch strength (Fig. 5). The stronger leaf tissue of gap-independent species protects them against herbivory and other damage and consequently enhances leaf longevity (Coley and Barone 1996). It is likely the result of a larger proportion of fibers (van Arendonk and Poorter 1994; Alvarez-Clare and Kitajima 2007), epidermis (Onoda et al. 2008) or cell wall in general (Lusk et al. 2010). This in turn should increase tissue density, although the relationship with leaf strength was not strong (Fig. 1; Supplemental Table 3). The result is a steep, more than proportional, increase in strength with LMA (Fig. 4). The higher $A_{\mathrm{DM}}$ of gap-dependent species indicates that their leaf tissue contained more mesophyll relative to other tissue (Terashima et al. 2006). The larger content of photosynthetic proteins was reflected in the higher $\mathrm{N}_{\mathrm{DM}}$. The results are consistent with the concept of

(a)

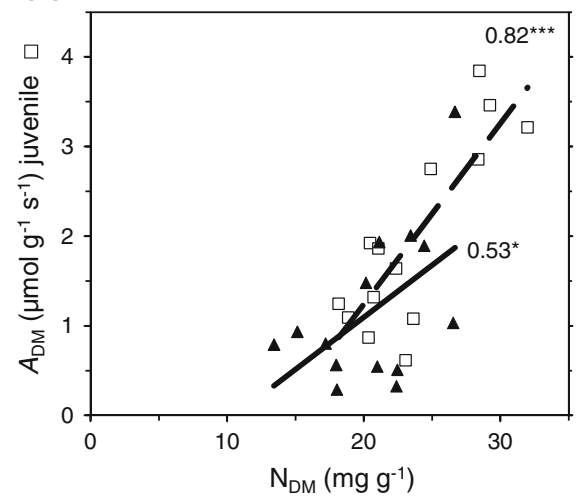

Fig. 5 Photosynthetic capacity per unit dry mass $\left(A_{D M}\right)$ plotted against leaf $\mathrm{N}$ concentration $\left(N_{D M}\right)$ (a) and against punch strength per dry mass (b). Significant correlations are depicted by thick regression lines. Juveniles are plotted on the left $Y$ axis (electron transport rates): a shift in the trade-off between the maximization of survival in shade of shade-tolerant evergreen tropical trees as opposed to light-requiring pioneers that maximize growth on the expense of longevity (Coley and Barone 1996; Poorter and Bongers 2006).

A smaller fraction of leaf $\mathrm{N}$ involved in photosynthesis in the shade-tolerant species could be the result of more $\mathrm{N}$ that is involved in structural reinforcement, such as cell walls (Onoda et al. 2004), and other defense functions in the stronger and longer-living leaves. Moreover, the possibly thicker mesophyll cell walls would result in a lower mesophyll conductance for $\mathrm{CO}_{2}$ diffusion (Terashima et al. 2006), and consequently in a lower efficiency of the photosynthetic proteins (Hikosaka et al. 1998; Pons and Westbeek 2004; Niinemets et al. 2009). These factors would contribute to a negative intercept of the $A_{\mathrm{DM}}-\mathrm{N}_{\mathrm{DM}}$ relationship (Fig. 5) and a decrease of $A_{\mathrm{N}}$ with shade tolerance (Fig. 2).

In evergreen tropical trees, a decrease in LMA with decreasing shade tolerance is often found (Kitajima 1994; Veneklaas and Poorter 1998; Lusk and Warton 2007; Lusk et al. 2008). However, only a weak negative trend was evident for the juveniles in our study (Table 3; Fig. 2). In a literature review, Veneklaas and Poorter (1998) found that the decrease of LMA with gap dependence is strongest for plants growing in low light. Since pioneers show generally a stronger increase of LMA at high irradiance (StraussDebenedetti and Bazzaz 1996; Veneklaas and Poorter 1998), the relationship becomes less clear for high lightgrown plants. Our juveniles were grown in a large gap, which is the likely explanation for the absence of a clear relationship of LMA with a species' gap dependence. The change in character of the leaf tissue referred to above occurred thus at a rather constant LMA. Apparently, the trade-off between leaf traits that enhance defense on the (b)

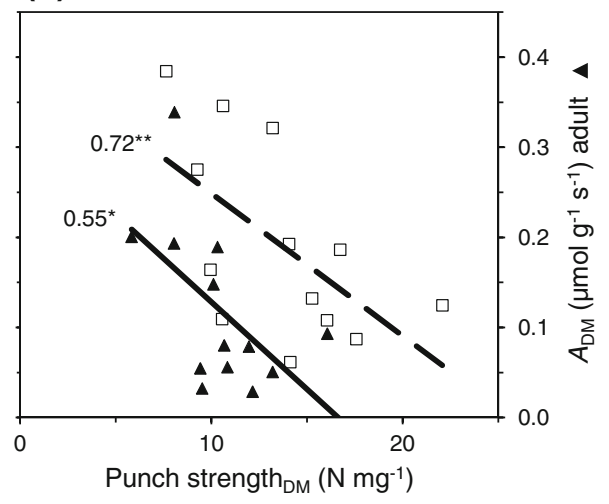

open squares and dashed lines. Adults are plotted on the right $Y$ axis $\left(\mathrm{O}_{2}\right.$ evolution rates): closed triangles and continuous lines. Correlation coefficients are shown next to the regression lines $(* P<0.05$; $* * * P<0.001)$ 
one hand and productivity on the other can also operate at an essentially constant LMA across a range of species' gap dependence as found for our gap-grown saplings (Figs. 1, 2 and 5). The character of the leaf tissue is thus a better predictor of shade tolerance than LMA in high light-grown tropical evergreens.

\section{Ontogenetic changes}

Several leaf traits changed substantially with ontogeny (Table 3) and the magnitude of the changes were different per species (Table 2; Supplemental Table 2). Shade-tolerant species cover a larger range of irradiance during growth to the canopy as compared to gap-dependent species. It could be hypothesized that they exhibit larger inherent changes during ontogeny. However, most relative changes in trait values were not correlated with the GAI, except for chlorophyll and nitrogen concentration (Table 4). These were also the traits that showed different associations in the PCA analysis between juveniles and adults.

An increase of LMA with tree size is universally found (Thomas and Winner 2002), including evergreen tropical rainforest trees (Thomas and Bazzaz 1999; Rijkers et al. 2000; Kitajima and Poorter 2010; Caveleri et al. 2010). We found on average a doubling of LMA when comparing exposed leaves of adult trees with small saplings growing in a large gap. The increase was somewhat stronger for gap-dependent species, resulting in complete absence of a trend of LMA with the GAI in adult trees (Table 3; Fig. 2). Mostly, an increase of LMA with shade tolerance is found in evergreen tropical trees, but these results are mostly based on studies with juveniles (Lusk and Warton 2007). Apparently, the relationship is not unequivocal in adults.

Increased LMA generally increases leaf strength (Wright and Cannon 2001; Onoda et al. 2008), which was also true for the ontogenetic change in our study (Fig. 2). However, contrary to the relationship with the interspecific variation in LMA, the large ontogenetic increase in LMA was associated with only a relatively small increase in punch strength (Fig. 4). This is strikingly similar to the small increase in punch strength with increasing LMA as a result of higher growth irradiance (Onoda et al. 2008, 2011; Lusk et al. 2010). Although tissue density increased with ontogeny (Fig. 3), it did not result in an increase in mass specific strength (Fig. 2). This contrasts with the study of Kitajima and Poorter (2010) who found a larger massspecific punch strength in adult tropical trees compared to saplings in Bolivia.

Electron transport is typically about five times higher than $\mathrm{O}_{2}$ evolution (Seaton and Walker 1990), but there may be species-specific variation in this factor. The different methods of photosynthesis measurement used for juveniles and adults thus prohibit a full quantitative comparison of the two ontogenetic stages. Additionally, a possible residual effect of the fertilizer may have increased $A_{\mathrm{LA}}$ and $A_{\mathrm{DM}}$ in juveniles somewhat. Although the results suggest a lower $A_{\mathrm{LA}}$ in particularly the shade-tolerant adult trees, no conclusions can be drawn on the ontogenetic changes, since differences were not large. However, the much larger differences between the ontogenetic stages leave little doubt that $A_{\mathrm{DM}}$ was lower in adults mainly as a result of their higher LMA. The possible residual fertilizer effect was probably not important for $A_{\mathrm{chl}}$ and $A_{\mathrm{N}}$, because photosynthetic capacity and chlorophyll tend to increase proportionally with leaf $\mathrm{N}$. The large differences thus suggest that $A_{\mathrm{chl}}$ and $A_{\mathrm{N}}$ tend to be lower in adults (Table 3; Fig. 2).

The lower photosynthetic nitrogen use efficiency $\left(A_{\mathrm{N}}\right)$ of adult trees compared to juveniles follows from a roughly similar $A_{\mathrm{LA}}$ at a much higher $\mathrm{N}_{\mathrm{LA}}$ (Table 3; Fig. 2). Increased LMA is often accompanied by a lower mesophyll conductance for $\mathrm{CO}_{2}$ diffusion (Flexas et al. 2008; Hassiotou et al. 2009; Niinemets et al. 2009). The reduced $A_{\mathrm{N}}$ of adult tree leaves would then partly be the result of reduced efficiency of the photosynthetic proteins and partly of the larger $\mathrm{N}$ investment in reinforcement structures in the form of cell wall proteins, although the latter may not be as straightforward as previously thought (Harrison et al. 2009). The stronger leaves in large trees are likely to be functional in the exposed parts of the adult tree crowns. Their structural reinforcement is important to cope with the abrasive action of branch and leaf movements in strong winds, and possibly larger water potential gradients. If so, the required increase in strength takes a substantial investment in dry matter, and goes on the expense of the efficiency of the use of carbon and nitrogen for photosynthesis $\left(A_{\mathrm{DM}}\right.$ and $\left.A_{\mathrm{N}}\right)$.

\section{Developmental constraint and adaptation}

Leaf traits showed similar associations for juveniles and adults (Fig. 1). The ranking of the species for several leaf traits was also similar for the two developmental stages (Table 4). This was particularly evident for leaf strength and photosynthetic parameters. It suggests that plasticity in the traits concerned is developmentally constrained (Thomas and Bazzaz 1999). In juveniles, chlorophyll, leaf strength, and photosynthetic capacity on all expression bases showed significant relationships with the GAI (Table 3). The conserved ranking means that leaf traits of adult trees are also related to the GAI, although, apart from the photosynthetic parameters, not as strong as for the juveniles (Table 3).

This raises the question regarding the cause of the correlation of adult leaf trait values with the regeneration niche. Poorter (2007) argued that these traits are selected in 
the juvenile phase and conserved in the adult phase as a result of developmental constraints. However, Thomas and Bazzaz (1999) showed a correlation of sapling photosynthetic trait values in late successional trees with adult stature, and thus light availability for the adult tree. They concluded that these traits are selected in the adult phase. Most of our high statured species are gap dependent and did not show a trend similar to the phenomenon described by Thomas and Bazzaz (1999) (results not shown). Also, Poorter (2007) did not find evidence for a relationship of leaf traits with adult stature. Martinez-Garza and Howe (2005) found greater changes in LMA and leaf size with ontogeny for tall species compared to short ones, which was interpreted as a reflection of the larger change in irradiance during growth.

Successional status is strongly correlated with leaf longevity (Reich et al. 1995; Poorter et al. 2004). Long-lived leaves improve long-term performance in shade because of the inherently long pay-back times of invested carbon (Poorter 1994; Westoby et al. 2002; Poorter and Bongers 2006; Selaya et al. 2008). However, long-lived leaves are also functional under other stress conditions such as low nutrient availability (Westoby et al. 2002). This increases the residence time of nutrients in the plant (Berendse and Aerts 1987; Aerts and Chapin 2000). The forest in Central Guyana where the study was carried out has a low nutrient status (van Kekem et al. 1996; Hammond 2005; Pons et al. 2007). However, the soil is transiently enriched after a larger disturbance (ter Steege et al. 1995). Hence, the gradient in light availability coincides to some extent with a gradient in nutrient availability. Leaves built for high productivity that are consequently short-lived are important for rapid growth (Lambers and Poorter 1992) at the transiently high nutrient availability shortly after a disturbance. This type of leaf is also functional in a canopy that is rapidly growing in height accompanied by fast leaf-turnover (Selaya and Anten 2010). At the other end of the light requirement spectrum, the suite of traits that enhances leaf longevity of juveniles in shade could also be functional in the adult phase for maintaining a position in the canopy of evergreen forest on nutrient poor soils.

\begin{abstract}
Acknowledgments The Guyana programme of Tropenbos International is thanked for providing financial and logistic support. Julian Pilay, Benedict Harry, Maureen Daniels and Mr. Ramdin are thanked for assistance with tree identification and sampling in the field. Yvonne de Jong-van Berkel did the nitrogen analyses. Lourens Poorter and Niels Anten are acknowledged for valuable comments on earlier drafts of the manuscript.
\end{abstract}

Open Access This article is distributed under the terms of the Creative Commons Attribution Noncommercial License which permits any noncommercial use, distribution, and reproduction in any medium, provided the original author(s) and source are credited.

\section{References}

Aerts R, Chapin FS (2000) The mineral nutrition of wild plants revisited: a re-evaluation of processes and patterns. Adv Ecol Res 30:1-67

Alvarez-Clare S, Kitajima K (2007) Physical defense traits enhance seedling survival of neotropical tree species. Funct Ecol 21:1044-1054

Anderson JM, Chow WS, Park YI (1995) The grand design of photosynthesis: acclimation of the photosynthetic apparatus to environmental cues. Photosynth Res 46:129-139

Aranwela N, Sanson G, Read J (1999) Methods of assessing leaffracture properties. New Phytol 144:369-383

Berendse F, Aerts R (1987) Nitrogen-use-efficiency: a biological meaningful definition? Funct Ecol 1:293-296

Bongers F, Popma J (1990) Leaf dynamics of seedlings of rain forest species in relation to canopy gaps. Oecologia 82:122-127

Cavaleri MA, Oberbauer SF, Clark DB, Clark DA, Ryan MG (2010) Height is more important than light in determining leaf morphology in a tropical forest. Ecology 91:1730-1739

Chazdon RL, Pearcy RW, Lee DW, Fetcher N (1996) Photosynthetic responses of tropical forest plants to contrasting light environments. In: Mulkey SS, Chazdon RL, Smith AP (eds) Tropical forest plant ecophysiology. Chapman and Hall, New York, pp 5-55

Choong MF, Lucas P, Ong JSY, Pereira B, Tan HTW, Turner IM (1992) Leaf fracture toughness and sclerophylly: their correations and ecological implications. New Phytol 121:597-610

Clark DA, Clark DB (1992) Life-history diversity of canopy and emergent trees in a neotropical rain-forest. Ecol Monogr 62:315-344

Coley PD, Barone JA (1996) Herbivory and plant defenses in tropical forests. Annu Rev Ecol Sys 27:305-335

Coley PD, Bryant JP, Chapin FS III (1985) Resource availability and plant antiherbivore defense. Science 230:895-899

Coste S, Roggy JC, Imbert P, Born C, Bonal D, Dreyer E (2005) Leaf photosynthetic traits of 14 tropical rain forest species in relation to leaf nitrogen concentration and shade tolerance. Tree Physiol 25:1127-1137

Evans JR (1989a) Partitioning of nitrogen between and within leaves grown under different irradiances. Aust J Plant Physiol $16: 533-548$

Evans JR (1989b) Photosynthesis-dependence on nitrogen partitioning. In: Lambers $\mathrm{H}$, Cambridge ML, Konings $\mathrm{H}$, Pons TL (eds) Causes and consequences of variation in growth rate and productivity of higher plants. SPB, The Hague, pp 159-174

Evans JR, Poorter H (2001) Photosynthetic acclimation of plants to growth irradiance: the relative importance of specific leaf area and nitrogen partitioning in maximizing carbon gain. Plant Cell Environ 24:755-767

Feeny P (1970) Seasonal changes in oak leaf tannins and nutrients as a cause of spring feeding by winter moth caterpillars. Ecology 51:565-581

Feng YL, Cao KF, Zhang JL (2004) Photosynthetic characteristics, dark respiration, and leaf mass per unit area in seedlings of four tropical tree species grown under three irradiances. Photosynthetica 42:431-437

Flexas J, Ribas-Carbo M, Diaz-Espejo A, Galmes J, Medrano H (2008) Mesophyll conductance to $\mathrm{CO}_{2}$ : current knowledge and future prospects. Plant Cell Environ 31:602-621

Genty B, Briantais JM, Baker NR (1989) The relationship between the quantum yield of photosynthetic electron transport and quenching of chlorophyll fluorescence. Biochim Biophys Acta 990:87-92 
Hammond DS (2005) Biophysical features of the Guiana shield. In: Hammond DS (ed) Tropical forests of the Guiana Shield. Ancient forests in a modern world. CABI, Wallingford, pp 15-194

Harrison MT, Edwards EJ, Farquhar GD, Nicotra AB, Evans JR (2009) Nitrogen in cell walls of sclerophyllous leaves accounts for little of the variation in photosynthetic nitrogen-use efficiency. Plant Cell Environ 32:259-270

Hassiotou F, Ludwig M, Renton M, Veneklaas EJ, Evans JR (2009) Influence of leaf dry mass per area, $\mathrm{CO}_{2}$, and irradiance on mesophyll conductance in sclerophylls. J Exp Bot 60:2303-2314

Hikosaka K, Hanba YT, Hirose T, Terashima I (1998) Photosynthetic nitrogen use efficiency in leaves of woody and herbaceous species. Funct Ecol 12:896-905

Hikosaka K, Terashima I (1996) Nitrogen partitioning among photosynthetic components and its consequence in sun and shade plants. Funct Ecol 10:335-343

Houter NC, Pons TL (2005) Gap size effects on photoinhibition in understorey saplings in tropical rainforest. Plant Ecol 179:43-51

Inskeep WP, Bloom PR (1985) Extinction coefficients of chlorophyll $\mathrm{a}$ and $\mathrm{b}$ in N, N-Dimethylformamide and $80 \%$ acetone. Plant Physiol 77:483-485

Kenzo T, Ichie T, Watanabe Y, Yoneda R, Ninomiya I, Koike T (2006) Changes in photosynthesis and leaf characteristics with tree height in five dipterocarp species in a tropical rain forest. Tree Physiol 26:865-873

Kitajima K (1994) Relative importance of photosynthetic traits and allocation patterns as correlates of seedling shade tolerance of 13 tropical trees. Oecologia 98:419-428

Kitajima K, Poorter L (2010) Tissue-level leaf toughness, but not lamina thickness, predicts sapling leaf lifespan and shade tolerance of tropical tree species. New Phytol 186:708-721

Kull O, Niinemets U (1998) Distribution of leaf photosynthetic properties in tree canopies: comparison of species with different shade tolerance. Funct Ecol 12:472-479

Lambers H, Chapin FS III, Pons TL (2008) Plant physiological ecology, 2nd edn. Springer, New York

Lambers H, Poorter H (1992) Inherent variation in growth rate between higher plants: a search for physiological causes and ecological consequences. Adv Ecol Res 23:187-261

Lusk CH, Onoda Y, Kooyman R, Gutierrez-Giron A (2010) Reconciling species-level vs plastic responses of evergreen leaf structure to light gradients: shade leaves punch above their weight. New Phytol 186:429-438

Lusk CH, Reich PB, Montgomery RA, Ackerly DD, Cavender-Bares J (2008) Why are evergreen leaves so contrary about shade? Trends Ecol Evol 23:299-303

Lusk CH, Warton DI (2007) Global meta-analysis shows that relationships of leaf mass per area with species shade tolerance depend on leaf habit and ontogeny. New Phytol 176:178-189

Martinez-Garza C, Howe HF (2005) Developmental strategy or immediate responses in leaf traits of tropical tree species? Int $\mathrm{J}$ Plant Sci 166:41-48

Matsuki S, Koike T (2006) Comparison of leaf life span, photosynthesis and defensive traits across seven species of deciduous broad-leaf tree seedlings. Ann Bot 97:813-817

Mooney HA, Gulmon SL (1982) Constraints on leaf structure and function in reference to herbivory. Bioscience 32:189-206

Mostacedo CB, Fredericksen TS (1999) Regeneration status of important tropical forest tree species in Bolivia: assessment and recommendations. For Ecol Manag 124:263-273

Murchie EH, Horton P (1997) Acclimation of photosynthesis to irradiance and spectral quality in British plant species: chlorophyll content, photosynthetic capacity and habitat preference. Plant Cell Environ 20:438-448
Niinemets U (1997) Role of foliar nitrogen in light harvesting and shade tolerance of four temperate deciduous woody species. Funct Ecol 11:518-531

Niinemets U (2006) The controversy over traits conferring shadetolerance in trees: ontogenetic changes revisited. $\mathrm{J}$ Ecol 94:464-470

Niinemets U, Wright IJ, Evans JR (2009) Leaf mesophyll diffusion conductance in 35 Australian sclerophylls covering a broad range of foliage structural and physiological variation. J Exp Bot 60:2433-2449

Onoda Y, Hikosaka K, Hirose T (2004) Allocation of nitrogen to cell walls decreases photosynthetic nitrogen-use efficiency. Funct Ecol 18:419-425

Onoda Y, Schieving F, Anten NPR (2008) Effects of light and nutrient availability on leaf mechanical properties of Plantago major: a conceptual approach. Ann Bot 101:727-736

Onoda Y, Westoby M, Adler PB, Choong AMF, Clissold FJ, Cornelissen JHC, Diaz S, Dominy NJ, Elgart A, Enrico L, Fine PVA, Howard JJ, Jalili A, Kitajima K, Kurokawa H, McArthur C, Lucas PW, Markesteijn L, Perez-Harguindeguy N, Poorter L, Richards L, Santiago LS, Sosinski EE, Van Bael SA, Warton DI, Wright IJ, Wright SJ, Yamashita N (2011) Global patterns of leaf mechanical properties. Ecol Lett 14:301-312

Osunkoya OO, Ash JE, Hopkins MS, Graham AW (1994) Influence of seed size and seedling ecological attributes on shade-tolerance of rain-forest tree species in northern Queensland. J Ecol 82:149-163

Pearcy RW (1987) Photosynthetic gas exchange responses of Australian tropical forest trees in canopy, gap and understory micro-environment. Funct Ecol 1:169-178

Pons TL, Anten NPR (2004) Is plasticity in partitioning of photosynthetic resources between and within leaves important for whole-plant carbon gain in canopies? Funct Ecol 18:802-811

Pons TL, Perreijn K, van Kessel C, Werger MJA (2007) Symbiotic nitrogen fixation in a tropical rainforest: ${ }^{15} \mathrm{~N}$ natural abundance measurements supported by experimental isotopic enrichment. New Phytol 173:154-167

Pons TL, Westbeek MHM (2004) Analysis of differences in photosynthetic nitrogen-use efficiency between four contrasting species. Physiol Plant 122:68-78

Poorter H (1994) Construction costs and payback time of biomass: a whole plant perspective. In: Roy J, Garnier E (eds) A whole plant perspective of carbon-nitrogen interactions. SPB, The Hague, pp 111-127

Poorter H, Evans JR (1998) Photosynthetic nitrogen use efficiency of species that differ inherently in specific leaf area. Oecologia 116:26-37

Poorter H, Niinemets U, Poorter L, Wright IJ, Villar R (2009) Causes and consequences of variation in leaf mass per area (LMA): a meta-analysis. New Phytol 182:565-588

Poorter L (2007) Are species adapted to their regeneration niche, adult niche, or both? Am Nat 169:433-442

Poorter L, Bongers F (2006) Leaf traits are good predictors of plant performance across 53 forest species. Ecology 87:1733-1743

Poorter L, van de Plassche M, Willems S, Boot RGA (2004) Leaf traits and herbivory rates of tropical tree species differing in successional status. Plant Biol 6:746-754

Popma J, Bongers F (1988) The effect of canopy gaps on growth and morphology of rainforest species. Oecologia 75:625-632

Raaimakers D, Boot RGA, Dijkstra P, Pot S, Pons T (1995) Photosynthetic rates in relation to leaf phosphorus content in pioneer versus climax tropical rainforest trees. Oecologia 102:120-125

Reich PB, Ellsworth DS, Uhl C (1995) Leaf carbon and nutrient assimilation and conservation in species of differing successional status in an oligotrophic Amazonian forest. Funct Ecol 9:65-76 
Reich PB, Walters MB, Ellsworth DS (1992) Leaf life-span in relation to leaf, plant, and stand characteristics among diverse ecosystems. Ecol Monogr 62:365-392

Rijkers T, Pons TL, Bongers F (2000) The effect of tree height and light availability on photosynthetic leaf traits of 4 neotropical species differing in shade tolerance. Funct Ecol 14:77-86

Rozendaal DMA, Hurtado VH, Poorter L (2006) Plasticity in leaf traits of 38 tropical tree species in response to light; relationships with light demand and adult stature. Funct Ecol 20:207-216

Seaton GGR, Walker DA (1990) Chlorophyll fluorescence as a measure of photosynthetic carbon assimilation. Proc R Soc Lond B 242:29-35

Selaya NG, Anten NPR (2010) Leaves of pioneer and latersuccessional trees have similar lifetime carbon gain in tropical secondary forest. Ecology 91:1102-1113

Selaya NG, Oomen RJ, Netten JJC, Werger MJA, Anten NPR (2008) Biomass allocation and leaf life span in relation to light interception by tropical forest plants during the first years of secondary succession. J Ecol 96:1211-1221

Strauss-Debenedetti S, Bazzaz FA (1996) Photosynthetic characteristics of tropical trees along a successional gradient. In: Mulkey S, Chazdon RL, Smith AP (eds) Tropical forest plant ecophysiology. Chapman and Hall, New York, pp 162-186

ter Steege H, Boot R, Brouwer L, Hammond DS, van der Hout P, Jetten VG, Khan Z, Polak AM, Raaimakers D, Zagt R (1995) Basic and applied research for sound rain forest management in Guyana. Ecol Appl 5:904-910

Terashima I, Hanba YT, Tazoe Y, Vyas P, Yano S (2006) Irradiance and phenotype: comparative eco-development of sun and shade leaves in relation to photosynthetic $\mathrm{CO}_{2}$ diffusion. J Exp Bot $57: 343-354$
Thomas SC, Bazzaz FA (1999) Asymptotic height as a predictor of photosynthetic characteristics in Malaysian rain forest trees. Ecology 80:1607-1622

Thomas SC, Winner WE (2002) Photosynthetic differences between saplings and adult trees: an integration of field results by metaanalysis. Tree Physiol 22:117-127

Valladares F, Niinemets U (2008) Shade tolerance, a key plant feature of complex nature and consequences. Annu Rev Ecol Evol Syst 39:237-257

van Arendonk JJCM, Poorter H (1994) The chemical composition and anatomical structure of leaves of grass species differing in relative growth rate. Plant Cell Environ 17:963-970

van Dam O (2001) Forest filled with gaps. Effects of gap size on water and nutrient cycling in tropical rain forest. A study in Guyana. Tropenbos-Guyana Series 10, Georgetown, Guyana

van Kekem AJ, Pulles JHM, Khan Z (1996) Soils of the rainforest in central Guyana. Tropenbos-Guyana Series 2, Georgetown, Guyana

Veneklaas EJ, Poorter L (1998) Growth and carbon partitioning of tropical tree seedlings in contrasting light environments. In: Lambers H, Poorter H, van Vuuren MMI (eds) Inherent variation in plant growth; physiological mechanisms and ecological consequences. Backhuys, Leiden, pp 337-361

Westoby M, Falster DS, Moles AT, Vesk PA, Wright IJ (2002) Plant ecological strategies: Some leading dimensions of variation between species. Annu Rev Ecol Syst 33:125-159

Wright IJ, Cannon K (2001) Relationships between leaf lifespan and structural defences in a low-nutrient, sclerophyll flora. Funct Ecol 15:351-359 